\title{
THE “LIVED RELIGION” OF EVANGELICAL CHRISTIAN-BAPTIST WOMEN IN SOVIET SIBERIA $(1945-1991)^{* * *}$
}

\author{
April L. French, \\ Brandeis University, \\ Waltham, USA
}

This article draws upon oral history interviews of Evangelical Christians-Baptists (ECB) in Siberia to examine the lived religion of evangelical women from 1945 to 1991 . The author conducted 41 interviews of 52 subjects, most of whom had participated in the ECB congregations of four provinces - Omsk Oblast, Novosibirsk Oblast, Krasnoyarsk Krai, and Irkutsk Oblast - during the Soviet period. By investigating the way ECB believers construct and interpret their experience of the Soviet period and the stories they tell of how faith informed women's lives and identities at home, in their congregations, and in the Soviet workplace, this article argues that ECB women played a vital role in preserving the faith of their families and congregations within a secularist state that saw them as dangerous sectarians. In this respect, the article examines the particular subcultural pressures that ECB women experienced and their roles in active leadership within their congregations. In addition, the article reconstructs the stories of two women - one from Krasnoyarsk and one from Omsk - in order to demonstrate that some ECB women's religious convictions were strengthened and confirmed just as much by their daily interactions with ardent atheists or Soviet and party functionaries as it was by relationships within their co-religionists.

Keywords: Evangelical Christians-Baptists; women; oral history; Soviet history; Siberia; lived religion.

* The author is grateful to Nadezhda Beliakova and Aleksei Beglov at the Center for the Study of Religion and the Church (Russian Academy of Sciences) for the opportunity to present on this topic in September 2016. The author also presented an earlier version of this article at the 2016 Baptist History and Heritage Conference in Waco, Texas, where she received feedback from Albert Wardin. Thanks to Kristen Lucken, Wendy Cadge, and Constantine Prokhorov who offered helpful advice before the interviews for this project began. Finally, thanks to the ECB believers who graciously offered their time and life stories to the author. A Fulbright Student Research Grant funded the research for this article.

** Citation: French, A. L. (2018). The "Lived Religion" of Evangelical ChristianBaptist Women in Soviet Siberia (1945-1991). In Quaestio Rossica, Vol. 6, № 2, p. 454-467. DOI 10.15826/qr.2018.2.306.

Цитирование: French A. L. The "Lived Religion" of Evangelical Christian-Baptist Women in Soviet Siberia (1945-1991) // Quaestio Rossica. Vol. 6. 2018. № 2. P. 454-467. DOI 10.15826/qr.2018.2.306.

(C) French A., 2018 
В статье на основе интервью рассматривается религиозность женщин в евангельских общинах с 1945 по 1991 г. Всего было проведено 41 интервью с 52 информантами, которые в советское время являлись членами общин евангельских христиан-баптистов (далее - ЕХБ) на территории Омской, Новосибирской и Иркутской областей и в Красноярском крае. Реконструируется и интерпретируется личный опыт женщин-евангелисток в советское время, в частности, устанавливается, какую роль играла вера в формировании их идентичности, какое влияние оказывала на повседневную жизнь, взаимоотношения в общинах и отношения на работе. Рассматривается роль женщин для поддержания веры в кругу семьи и за ее пределами в условиях атеистического окружения. Исследуются формы давления, которые женщины ЕХБ испытали в советское время, и их активная роль лидеров в религиозных общинах. На основе реконструкции жизненного опыта двух женщин-евангелисток автор утверждает, что их религиозные убеждения укреплялись не только благодаря активному общению с членами общины, но и в результате практически ежедневного противостояния с убежденными атеистами, советскими и партийными чиновниками.

Ключевые слова: евангельские христиане-баптисты; женщины; устная история; советская история; Сибирь; повседневная религиозность.

Most historians of the Evangelical Christian-Baptist (ECB) denomination in the former Soviet Union have focused on the story of male leaders or of congregations more generally [Sawatsky; История евангельских христианбаптистов в СССР; Савинский; Альманах по истории русского баптизма; Coleman; Никольская; Prokhorov]. Yet the story of ECB women, who regularly constituted 75 to 80 percent of their church membership in the late Soviet period, has until recently been marginalized (noteworthy recent exceptions: [Кондрашина; Dobson; Белякова, Добсон; Beliakova, Dobson]). Drawing upon oral history interviews conducted with individuals who attended ECB congregations in Siberia, this article considers the underexamined aspects of ECB women's "lived religion" in the late Soviet period. Lived religion, as defined by Robert Orsi [Orsi, p. XXXIX], is "the work of social agents/actors themselves as narrators and interpreters (and reinterpreters) of their own experiences and histories, recognizing that the stories we [scholars] tell about others exist alongside the many and varied stor[ies] they tell of themselves" (see also: [Lived Religion in America]).

This article will focus on three of these modes - ECB women as mothers, as participants in their congregations, and as workers in the Soviet workplace. By investigating the way ECB believers construct and interpret their lived experience of the Soviet period and the stories they tell of how faith informed women's lives and identities at home, in their congregations, and in the Soviet workplace, this article will examine (a) the influence of women's encounters with party and state actors upon their religious convictions and (b) the role women played in their families and congregations. 


\section{Methodology}

Historians have recently utilized oral history in their work on Sovietera Protestants [Подвиг веры; Белякова, Добсон; Beliakova, Dobson; Белякова, Клюева]. In particular, Nadezhda Beliakova and Miriam Dobson, have observed that the believers they interviewed were "motivated by a desire... to report the truth [of their situations] and to preserve their memory for future generations", as well as "to present pertinent information to the secular public about the life and history of evangelical communities" [Dobson, p. 37]. Not only is oral history useful for the preservation of believers' lived experience, but it is also an effective means by which scholars can explore "the female dimension of religiosity... [and] the central role performed by women as key conduits of belief", as Sarah C. Williams argues [Dobson, p. 27].

The author conducted 41 interviews from December 2014 to July 2015 with 52 ECB subjects, only some of which are cited in this article. Most interview subjects had regularly participated in ECB communities in $\mathrm{Si}$ beria - particularly Omsk Oblast, Novosibirsk Oblast, Krasnoyarsk Krai, and Irkutsk Oblast - in the Soviet period.

Brandeis University (IRB Protocol \#14165) regulated these interviews, the goal of which was to offer ECB believers the opportunity to tell their stories while assessing how their religious convictions influenced their daily lives. The interviewer began each interview with an open-ended request that the interviewee tell the story of their spiritual journey. During the course of fulfilling that request, most interviewees naturally addressed their experiences with God, life at home, relationships and teachings in their congregations, and encounters with unbelievers in educational institutions and the workplace. If they did not naturally discuss such things, the interviewer would ask them more direct questions.

Although the registered and unregistered status of congregations fluctuated in the post-war period, interview subjects included 30 women and 11 men who were usually part of registered congregations and 7 women and 3 men who were usually part of unregistered congregations (after the union-wide denominational split that took place in the early 1960s) ${ }^{1}$. Despite this imbalance, the author still gleaned information about everyday life from key individuals in the unregistered ECB churches in Irkutsk and Omsk. In addition to formal interviews, the author also conducted three informal conversational interviews with two men and one couple. Most interview subjects gave the author permission to use their full names in published work, but initials will be used in this article. The author has all recordings, informed consent forms, and transcripts in her possession. Upon completion of her published work with these interviews, she will donate the materials for those subjects who gave express permission to one archive in Russia and one archive in the USA.

${ }^{1}$ Of the 51 interview subjects for the author's larger project, 22 are cited within and listed at the end of this article. 


\section{The Baptistka and the Atheist}

One of the more remarkable interviews for this project took place in Krasnoyarsk with OPM ${ }^{2}$ (1937-2015). Three weeks before the interview, doctors had given her only three weeks to live due to cancer; she died two months after the interview. On the day of the interview, she was lucid and had a resolved purpose to tell her story one final time. Her opening remark was, "It was the Communists who pushed me to the Baptists"3. She had grown up fully indoctrinated into the Communist credo. "We were patriots in spirit, at our very essence", - she said. OPM had been a devoted member of the Communist Youth organization (Komsomol) and had fully intended to become a member of the Communist Party.

In 1955, however, OPM's cousin invited her to an ECB prayer meeting, which met in an overcrowded, stuffy basement room where she nearly fainted from the heat. As she describes it, she "realized that there is a God, and an internal struggle began". While she did not make a decision that day to become a Baptist, she decided she could no longer be a Komsomol member, since it was "not honest to carry a Komsomol membership card and to know that God exists". The next day, she naïvely took her membership card to the Komsomol secretary at her factory. In response, he immediately called the factory's Komsomol organization to gather, where her co-workers proceeded to mock her for thinking that any god existed. Looking back, OPM sees that her "inroads into the Baptist faith began from that day forward". The eighteen-year-old endured several weeks of merciless taunting at the combine factory, with co-workers saying, "There goes an American spy!" or, "Look, here comes a baptistka [a Baptist girl]!" OPM said she "went to work each day as if to Golgotha" due to this incessant "persecution". During that time, she made a firm decision, "Whether I become a believer or not, I will absolutely never be with these people!"

The district Komsomol committee eventually summoned OPM to their headquarters to interrogate her, and she surrendered her Komsomol card to them. She reported experiencing both overwhelming anxiety and a deep sense that God had acted through her: "I understood that I had done something from which there was no return". Not long after withdrawing from the Komsomol, she chose to quit her studies at the highly competitive mechanics' course at Krasnoyarsk's Technical Institute, because she believed that she "could not withstand another attempt [by those in authority] to morally wound" her, and she moved 50 kilometers away from Krasnoyarsk to her mother's village to work in a glass factory where no one knew of her connection to the Baptists. She acknowledged having regretted her decision to quit the institute for the rest of her life.

2 The author has chosen to use abbreviations or pseudonyms in place of interview subjects' full names for this particular article.

${ }^{3}$ The author has translated all Russian sources for this article into English. 
Meanwhile, according to OPM, a man was sent to the combine factory to inspect its Komsomol records and saw the minutes of the meeting where she had been taunted for having relinquished her Komsomol membership. This young man had enrolled as a student at the Krasnoyarsk Pedagogical Institute in the late 1950s and was an instructor for the city's Komsomol organization. OPM described him as "a no-nonsense Komsomolets". According to her, this man became so upset at how poorly the factory's Komsomol organization had dealt with the situation that he made sure its secretary was removed from his post. He somehow discovered where OPM lived, and late one bitter cold Siberian evening, he knocked on her door. When she described opening the door and seeing this man for the first time, she said, "I understood that he had come for my soul". According to her, he told the village factory's Komsomol secretary about her connections with the Baptists. After that, the co-worker whom she had intended to marry never spoke to her again. "It is devastating to endure [the loss of] one's first love, extremely difficult", she recalled. She stopped going to dances and clubs and began to attend Baptist prayer meetings with her relatives in the village and to learn Baptist hymns. When she returned to Krasnoyarsk to study at a technical college for construction, she became a regular attendee at the registered Baptist church, where she converted one day in the late 1950s, starting a relationship with God, whom evangelicals saw as their true First Love (Rev. 2:4).

During much of the interview, OPM described the extensive disruption that this person caused in her life, especially in the 1960s, and the way his ardency actually drove her further into the arms of the Baptist congregation, where she was finally baptized in 1967. Despite all this, she said that he "sincerely fought for the youth", being fully convinced that she and others were being led astray by a dangerous ideology. In fact, the phone rang in the middle of the interview, and when her son returned from having answered it, he announced that it had been that very person, calling to see how she was doing! As it turned out, the two had managed to build a respectful relationship over the course of six decades 4 .

This man's daughter included a brief description of her father's relationship with OPM in an interview. Her account of how the two met differs from OPM's account:

One day, on the city's radio station, father heard a broadcast that was unusual for that period. It was about a girl who had been fired from work and expelled from the institute because she became a believer, a Baptist. Outraged at such injustice, father called the radio station, discovered where this unfortunate person lived and set off to save her. He succeeded in restoring her place at work and at the institute, but the fact that [OPM] had ended up 'in the clutches of sectarians' did not give him a moment's peace. That was approximately 1960 .

${ }^{4}$ The author regrets not being able to interview this man, due to schedule constraints while in Krasnoyarsk. For scholarly works that incorporate interviews of Soviet scholars of religion and atheistic workers, see: [Luehrmann; Смолкин-Ротрок; Smolkin-Rothrock]. 
I will note, jumping ahead, that even today, elderly [OPM] continues to be friendly with my parents and has become almost like a relative to our family. But she has remained a Baptist. It was this incident that first brought [my father] into contact with those groups of believers, who in the Soviet Socialist period seemed alien and an atavism of a shady past [Григорьева].

Although the two accounts of their first meeting differ substantially, what remains constant is that the initial meeting between these two people influenced the trajectory of each of their lives and that they somehow managed to maintain a respectful relationship, despite his persistent efforts to extract her from what he perceived to be "an atavism of a shady past".

OPM's story highlights the way one woman's everyday life was influenced and changed by her encounter with a passionate individual who was convinced that he was trying to save her from a dangerous religious group. But it also demonstrates the significance of her faith in other aspects of her everyday life. As OPM shared her story, she identified herself as a member of a family, a member of a church, and a citizen of the Soviet Union. She was a wife in a short-lived marriage to an abusive husband who was an unbeliever and a single mother of two sons whom she "always took to church"; a "sister in Christ" within her ECB congregation in Krasnoyarsk; and a dedicated worker at a military factory that could not fire her, despite her problematic faith, since she was too valuable a worker. Indeed, most interviewees identified themselves with a similar focus on the complex, intersecting spheres of home, church, and workplace, to which we now turn.

\section{Mothers as Spiritual Models}

In the Siberian Baptist home, the figure of the mother looms large. In fact, interviewees' depictions of their pious mothers were so ubiquitous that the theme of the mother as a conduit of faith to the next generation cannot be ignored. Multiple interviewees, when asked to tell about their spiritual journey, began their stories with the statement, "Well, my mother was a believer" (FG, RP, ANS, SSS, IST, LFV). Many saw their mothers as spiritual models in the way they lived out their faith in the home, in their church communities, and in wider society (ABC, LAG, "Good Son", VEK, LNS, LFS, MNS).

In ECB communities, the pressure to raise children who would fervently believe as adults was exceptionally high. One interviewee, when asked what responsibilities women had in the church, replied, "Above all, a woman must be a light in her family. She should be... such a light that her children would come to know God [through her]" (ASD, emphasis added). This statement from a childless woman demonstrates the cultural discourse that evangelical women imbibed while taking part in their religious meetings, particularly the expectation placed upon mothers to raise their children correctly in the midst of a society that was trying to impart upon them an atheist upbringing. 
Indeed, children of believing parents became sites of conflict between their parents, who were convinced that God had called them to give their children a Christian upbringing, and school officials, who were mandated from above to give children an atheist upbringing. The city of Omsk, where ECB believers and their children were persistently subjected to administrative and prophylactic oppression both before and after the union-wide ECB split, provides a clear case study for this. In May 1971, when four leaders of the Omsk unregistered ECB congregation had been arrested and were awaiting trial, a schoolgirl whose mother was a member of that church was called in to the school director's office, where she was interrogated by a pretrial investigator who presumably wanted to find out what these four men had been teaching her at church. Her schoolmate saw what was happening and ran to inform her friend's mother FG, who ran quickly to the school, opened the door to the director's office and told her daughter to leave the room immediately. Relieved that her mother had come to her rescue, the girl left the room; FG refused to stay, leaving the school with her daughter. According to FG, a day or two later, she was summoned to the investigator's office, where she defended her actions, saying, "If our children are in any danger... we parents must defend them". At that point in the story, she turned to the interviewer and said, "Those parents who would say, 'Let the children figure things out for themselves', it is their children who have left [the church] for the world and have become unbelievers. We must defend our children" (Interview with FG).

In the early 1980s, when LNS (the daughter of one of the four who had been arrested in 1971) was in grade four, she endured merciless taunting and beatings at the hands of her classmates many days on her way home from school. One day, when her class was standing around a small table for a lunch of rice porridge, one of her classmates yelled, "Baptistka! We need to beat Baptists!" He rammed the table into LNS and trapped her against the wall behind her, repeating this several times before throwing his bowl of porridge at her. Covered in porridge and mortified at the way she was treated, LNS fled the cafeteria, grabbed her things, and decided she would never return to school again. Upon hearing about this, LNS's mother told school officials, "I will write a letter to the government, because such things absolutely must not continue". This was no veiled threat. LNS's mother LLS had been an assistant for the Siberian contingent of the Council of Prisoners' Relatives since 1975 and had been writing and signing protest letters to Soviet officials since at least 1968 [Родственники узников Западной Сибири]. She was, therefore, accustomed to writing, signing, and mailing letters to government officials concerning the violation of the human rights of her family and co-religionists. According to LNS, school officials begged her mother not to write such a letter and promised things would change. They transferred the culprit to another school. LNS, who returned to school, admitted that although such severe treatment ceased, she still regularly faced less severe harassment while at that school. 
Concerning the subcultural expectation of raising children to be strong believers, many ECB women proved equal to the task. YKS extolled his mother as a spiritual model. After praising her for her hard work at feeding twelve children while living in dire poverty in a small urban center in the Omsk Oblast, he discussed her spiritual example:

Concerning spirituality, I see [my mother] in such an uncomplaining motherly ministry that she [took on the role] as a pastor's wife uncomplainingly... For a woman, this role demanded back-breaking labor [because fathers in ministry were gone so often... Mama was a saint... Mama was a model of a Christian woman, a humble model of a woman, a model of a mother. When she was left alone with her children, because they [local authorities] had taken our father, fellow sisters in Christ would come to our home. They would open the Bible, read it, discuss things, weep a little, and pray together (Interview with YKS) ${ }^{5}$.

Like YKS's mother, ECB women who were housewives took on much of the task of providing their children with a spiritual upbringing, knowing that their children's future choices to believe or not to believe would be seen as a reflection of the success of their efforts (LSS, VAS). In contrast, working mothers - who faced the same pressure for their children to become strong believers - discussed the daily challenges they faced and the subsequent difficulties in providing a Christian upbringing within the home (APB, OPM). Yet, even those who admitted that their mothers were so busy with the double burden of workplace and home life that they were unable to directly impart a Christian upbringing to their children - aside from taking them to church regularly - were quick to note that they valued their mothers' holy living, whether exhibited through their loving nature, generosity, and hospitality; the way they responded graciously to hostile coworkers or supervisors; or the way their neighbors saw them as "angels" (LAG, "Good Son”, SSS).

\section{ECB Women in Ministry}

Not only was women's spiritual influence crucial at home, but it was also essential in their worshipping communities, particularly in their ministry to children and youth and in their discipleship of other women. In Novosibirsk, through a series of formal and informal interviews, the author discovered that two key ECB leaders attributed their early spiritual formation as preachers and leaders to two women who led their youth group in the 1970s. These men, who adhere to a strict interpretation of Scripture with respect to male leadership in churches, claimed proudly and respectfully that these two women taught them how to preach (EAG; see also: [Кононенко]). Meanwhile, the younger of the two women, SSS, down-

\footnotetext{
${ }^{5}$ YKS's father was sentenced to five years in prison in 1961. He would later become a key provincial and national leader for the registered ECB denomination.
} 
played her ministry in an interview, suggesting that she merely encouraged the two young men in their first attempts at leading Bible study and preaching.

During another interview, RP praised her first discipler, a German woman who was a deaconess in the registered ECB church in Omsk. RP received the following letter from her when she was baptized in 1976 (recited by heart during the interview):

You have now stepped forth to follow the Lord. Tell this to your household firmly and decisively, but peacefully, with love. Follow the Lord. Feed on the Word of God. Read it often. Remain in fellowship with the church. Do not forsake gathering [with fellow believers]. Even the smallest transgression is dangerous. Take it quickly to Christ. The Lord will forgive every sin, every transgression, whether large or small. Bow before Him, ask forgiveness. And do not be afraid.

Love you, (NP).

Rufina's sponsor gave her a notebook full of scriptural affirmations. In the context of a severe shortage of Bibles and no opportunities for an official theological education, such notebooks often worked in conjunction with Baptist hymnals to form the backbone of women's theological knowledge.

Historian Constantine Prokhorov considers the demographic preponderance of women one of several "serious internal weaknesses" of late-Soviet ECB churches [Prokhorov, p. 20]. Yet, the roles played by women like SSS in Novosibirsk and NP in Omsk were vital for the ongoing health of their ECB congregations. Indeed, women in Soviet Siberia were an integral part of their communities, sustaining theological cohesion, an evangelistic impulse, and spiritual and social bonds through their readiness to "lead from within".

\section{ECB Women in the Soviet Workplace}

The Soviet workplace was a regular site of encounter between evangelical believers and "the outside world". Standard images of ECB women in the Soviet Union consist either of dutiful housewives with large broods of children or of elderly retirees. Yet, women from each ECB congregation were employed in jobs such as nursing, sewing, agriculture, and factory work, demonstrating that this reductionist image must be expanded.

ASD worked at a factory in Omsk during the Great Fatherland War (WWII). In 1944, her coworker invited her to a Baptist gathering at a private home. ASD loved the hymns, and the sermon touched her so much that the following week, she took her entire family - her parents, brother and sister-in-law. Soon, they had all converted. She was baptized in June 1945, along with nine other people, including Georgii Vins (1928-1998), 
who would later become a well-known leader of the unregistered Council of ECB Churches.

By the end of the war, ASD had enrolled in a medical technical college and passed her courses at the top of her class. She started working at a prison hospital run by the Ministry of Internal Affairs. In 1949, she married a factory worker who had been baptized a year earlier. ASD worked for over thirty years as a nurse, most of those years at a medical clinic, after transferring from the prison hospital. All the while, she was an active member of her church, singing alto in the choir, organizing special events, hosting visiting preachers, and serving as a night attendant. ASD loved her job, recalling that she constantly prayed for her coworkers and patients. She explained that since she wanted to glorify God in everything, she did the best work she could, always having superiorly starched uniforms; writing reports concisely and accurately; and politely interacting with everyone she encountered, even when they were impolite toward her. In so doing, she was trying to live by the biblical concept of "working as unto the Lord" (Col. 3 : 23).

During the interview, ASD recounted two stories of particular importance. The first story involved a time when the party secretary of the Oktiabrskii District in Omsk denounced her in a speech at the sixtiethanniversary celebration of the October Revolution. The party secretary announced, "A baptistka in our organization receives illegal literature from America and attends an unregistered prayer house. We have assigned a radiologist [at her workplace] to re-educate (ASD)". At the pronouncement, the crowd gasped, and a co-worker turned to ASD, saying, "We never knew you were an enemy of the people!" She claims to have felt at that moment like Christ on the cross when all his friends had abandoned him. The next day, the clinic's head doctor and party secretary, two women ASD knew well, approached her at work to discuss the denunciation. She denied having received any literature from the United States and explained that she was in fact a member of the registered ECB church, which could be easily proven by the congregational lists kept by the provincial commissioner of the Council for Religious Affairs ${ }^{6}$. The clinic's party secretary said, "How dare that person say such lies about you!" She then turned to the head doctor and said, "I've been summoned to a meeting with the city's party committee. Shall I report that you have educated (ASD)?" The head doctor laughed, "Yes, she has been re-educated". The clinic's party secretary vigorously defended ASD the next day before her superiors. Recounting these events four decades later, ASD interpreted her employer's defense as divine favor, saying, "I see God's hand in this".

Second, ASD recalled having been put in charge of preparing a patient for a surgical procedure to be conducted by a well-respected surgeon in the city. Following the surgery, she overheard an exchange between the surgeon and another nurse at the medical clinic. The surgeon said, "I just love

6 Confirmed in the archival record: [ИАОО. Ф. Р-2603. Оп. 1. Д. 43. Л. 3-5 об.; Оп. 1. Д. 49. Л. 6-22]. 
that nurse (ASD)". The nurse replied, "But she is a baptistka!" According to ASD, the surgeon replied, "It's fine that she is a baptistka. She is reliable and honest, and I appreciate her".

ASD's stories demonstrate three patterns in evangelical women's employment. First, their religious beliefs regularly had a positive influence on the quality of their work. Second, some state and party officials occasionally ignored "sectarian" women's contributions to the workplace and instead portrayed them as treasonous criminals. Finally, employers or co-workers could play an important role in the retention or dismissal of evangelical women workers. ASD's example of her superiors defending her against false accusations or suspicions was not altogether atypical (TGP, SSS, VAC), indicating that not every state or party functionary saw their co-workers' or employees' faith as sufficiently dangerous to lead them to take active measures against so-called sectarians.

Oral history allows researchers to understand the everyday life of those who were often deemed "dangerous sectarians" by those whose records are kept in Soviet archives. The constructed narratives of OPM and ASD indicate that ECB women's daily interactions with zealous atheists strengthened their religious convictions. Both women's stories reflect a certain ambiguity with respect to their encounters with Komsomol and Communist Party members. In OPM's case, although her repeated encounters with atheists "pushed" her toward the Baptists and away from the Communist Party, she and a key player in the atheistic frontline maintained at least a modicum of mutual respect. In ASD's case, despite the fact that a high-ranking party official several degrees removed from her medical clinic reported misinformation about her in a public setting that impacted her negatively by inciting fear and suspicion in her co-workers, her supervisors were willing to defend her to those ranked above and below them.

In addition, ECB women played a vital role in preserving the faith of their families and congregations. From a very young age, ECB women were inculcated with the expectation that mothers are responsible for raising their children to be faithful believers. Women often experienced this as external pressure, but many interview subjects acclaimed their mothers as spiritual models of good character. Moreover, despite the theological conviction that only men could lead congregations, women played an active role in teaching and mentoring men and women via their ministry to youth and their discipleship of other women.

The constructed narratives of ECB believers shed significant light on the way they understood and interpreted women's roles and experiences. ECB women - in their roles as mothers, "sisters in Christ", and youth leaders actively sought to shape the religious foundations of future generations, thereby preserving the Baptist faith. In their role as workers, ECB women saw their work ethic and collegial relationships in the Soviet workplace as 
informed by their faith, despite the suspicion they experienced from certain co-workers and employers. And although some believers left their churches after encounters with atheistic workers, some women look back on such encounters as catalysts for the further shaping and strengthening of their religious convictions (see: [Мы были баптистами]).

\title{
List of interviews (alphabetical by first initial, preserved in author's personal archive)
}

\author{
ABC (b. 1941), Krasnoyarsk, March 19, 2015. \\ ANS (b. 1926), Novosibirsk, April 22, 2015. \\ APB (b. 1935), Minusinsk, March 9, 2015. \\ ASD (b. 1923), Omsk, December 11, 2014. \\ EAG (b. 1954), Novosibirsk, May 9, 2015. \\ FG (b. 1934), Omsk, June 9, 2015. \\ "Good Son" (b. 1940s), Minusinsk, March 8, 2015. \\ IST (b. 1958), Irkutsk, March 31, 2015. \\ LAG (b. 1957), Novosibirsk, May 11, 2015. \\ LFS (b. 1950), Krasnoyarsk, February 26, 2015. \\ LFV (b. 1950), Irkutsk, April 13, 2015. \\ LLS (b. 1931), Omsk, June 2 and 9, 2015. \\ LNS (b. 1971), Omsk, June 2, 2015. \\ MNS (b. 1923), Novosibirsk, April 29, 2015. \\ OPM (1937-2015), Krasnoyarsk, March 19, 2015. \\ RP (b. 1938), Omsk, December 17, 2014. \\ SSS (b. 1950), Novosibirsk, April 27, 2015. \\ TGP (b. 1921), Omsk, June 7, 2015. \\ VAC (b. 1949), Minusinsk, March 10, 2015. \\ VAS (b. 1960), Irkutsk, April 14, 2015. \\ VEK (b. 1932), Minusinsk, March 9, 2015.
}

\section{Список литературы}

Альманах по истории русского баптизма : в 4 вып. / сост. М. С. Каретникова. СПб. : Библия для всех, 1999-2009. Вып. 1. 313 с. Вып. 2. 431 с. Вып. 3. 352 с. Вып. 4. 302 с.

Белякова Н. А., Добсон М. Женщины в евангельских общинах в послевоенном СССР. 1940-1980-е гг. : Исследование и источники. М. : Индрик, 2015. 511 с.

Белякова Н. А., Клюева В. П. Духовные поиски евангельских верующих в послевоенного СССР // Диалог со временем. 2016. № 55. С. 311-329.

Григорьева Л. И. «В религиоведение я ниоткуда не приходила. Я в нем родилась, сформировалась и выросла» : интервью с Людмилой Ильиничной Григорьевой // Телескоп [сайт]. 2013. № 5-6. URL: www.socioprognoz.ru/files/File/1/grigorieva.pdf (дата обращения: 14.04.2017).

ИАОО. Ф. Р-2603. Оп. 1. Д. 43, 49.

История евангельских христиан-баптистов в СССР. М. : ВСЕХБ, 1989. 624 с.

Кондрашина Е. Женщины в общинной жизни протестантских церквей в СССР (1945-1991 гг.) // Государство, религия и церковь в России и за рубежом. 2014. Т. 32. Вып. 1. С. 151-171.

Кононенко Ю. Может ли девушка руководить молодежью? // 95 лет Церкви ЕХБ в Новосибирске. Новосибирск : Посох, 1998. С. 33.

Мы были баптистами / под ред. В. И. Голубовича. М. : РОССПЭН, 1960. 111 с.

Никольская T. К. Русский протестантизм и государственная власть в 1905-1991 годах. СПб. : Изд-во Европ. ун-та, 2002. 356 с. 
Подвиг веры: уникальные свидетельства о жизни христиан в СССР / сост. и ред. К. Прохоров. Омск : Наука, 2010. 400 с.

Родственники узников Западной Сибири : Заявление Председателю Совета Министров т. Косыгину (8 августа 1968 г.) // Keston Center for Religion, Politics, and Society. SU-Ini-6-8-S. 3 p.

Савинский С. Н. История евангельских христиан-баптистов Украины, России, Белоруссии : в 2 т. СПб. : Библия для всех, 2001. Т. 2. 1917-1967 гг. 440 с.

Смолкин-Ротрок В. Интервью с профессором Николаем Семеновичем Гордиенко // Путь ученого : Николай Семенович Гордиенко / под ред. М. Ю. Смирнова. М. : Особая книга, 2013. С. 25-61.

Beliakova N., Dobson M. Protestant Women in the Late Soviet Era : Gender, Authority, and Dissent // Canadian Slavonic Papers. 2016. Vol. 52, no. 2. P. 117-140.

Coleman H. J. Russian Baptists and Spiritual Revolution, 1905-1929. Bloomington : Indiana Univ. Press, 2005. 305 p.

Dobson M. Child Sacrifice in the Soviet Press : Sensationalism and the 'Sectarian' in the Post-Stalin Era // The Russian Rev. 2014. Vol. 73. P. 237-259.

Lived Religion in America : Toward a History of Practice / ed. by D. D. Hall. Princeton : Princeton Univ. Press, 1997. 254 p.

Luehrmann S. Secularism Soviet Style: Teaching Atheism and Religion in a Volga Republic. Bloomington : Indiana Univ. Press, 2011. 276 p.

Orsi $R$. The Madonna of $115^{\text {th }}$ Street : Faith and Community in Italian Harlem, 18801950. N. Haven : Yale Univ. Press, 2002. 287 p.

Prokhorov C. Russian Baptists and Orthodoxy, 1960-1990 : A Comparative Study of Theology, Liturgy, and Traditions. Carlisle : Langham Monographs, 2013. 487 p.

Raleigh D. J. Soviet Baby Boomers : An Oral History of Russia's Cold War Generation. N. Y. : Oxford Univ. Press, 2012. 420 p.

Sawatsky W. Soviet Evangelicals since World War II. Scottdale ; Pennsylvania: Herald Press, 1981. 528 p.

Smolkin-Rothrock $V$. 'The Confession of an Atheist Who Became a Scholar of Religion' : Nikolai Semenovich Gordienko’s Last Interview // Kritika. 2014. Vol. 15, no. 3. P. 597-620.

Williams $S$. C. The Problem of Belief : The Place of Oral History in the Study of Popular Religion // Oral History. 1996. Vol. 24, no. 2. P. 27-34.

\section{References}

Beliakova, N., Dobson, M. (2016). Protestant Women in the Late Soviet Era: Gender, Authority, and Dissent. In Canadian Slavonic Papers. Vol. 52. No. 2, pp. 117-140.

Belyakova, N.A. Klyueva, V. P. (2016). Dukhovnye poiski evangel'skikh veruyushchikh v poslevoennom SSSR [The Spiritual Explorations of Evangelical Believers in Post-War USSR]. In Dialog so vremenem. No. 55, pp. 311-329.

Belyakova, N. A., Dobson, M. (2015). Zhenshchiny v evangel'skikh obshchinakh v poslevoennom SSSR. 1940-1980-e gg. Issledovanie i istochniki [Women in the Evangelical Congregations of Post-War USSR, 1940-1980s]. Moscow, Indrik. 511 p.

Coleman, H. J. (2005). Russian Baptists and Spiritual Revolution, 1905-1929. Bloomington, Indiana Univ. Press. 305 p.

Dobson, M. (2014). Child Sacrifice in the Soviet Press: Sensationalism and the 'Sectarian' in the Post-Stalin Era. In The Russian Rev. Vol. 73, pp. 237-259.

Golubovich, V. I. (Ed.). (1960). My byli baptistami [We Used to be Baptists]. Moscow, ROSSPEN. 111 p.

Grigor'eva, L. I. (2013). 'V religiovedenie ya niotkuda ne prikhodila. Ya v nem rodilas', sformirovalas' i vyrosla': Interv'yu s Lyudmiloi Il'inichnoi Grigor'evoi ['I Did not Arrive at Religious Studies from Anywhere. I Was Born, Shaped, and Raised within Them: An Interview with Lyudmila Il'inichna Grigor'eva]. In Teleskop. No. 5-6. URL: www.socioprognoz.ru/files/File/1/grigorieva.pdf (mode of access: 14.07.2017).

Hall, D. D. (Ed.). (1997). Lived Religion in America: Toward a History of Practice. Princeton, Princeton Univ. Press. 254 p. 
IAOO [State Historical Archive of Omsk Oblast]. Stock R-2603. List 1. Dos. 43, 49.

Istoriya Evangel'skikh khristian-baptistov v SSSR [The History of the Evangelical Christians-Baptists in the USSR]. (1989). Moscow, Vsesoyuznyi sovet evangel'skikh khristian-baptistov. $624 \mathrm{p}$.

Karetnikova, M. S. (Ed.). (1999-2009). Al'manakh po istorii Russkogo Baptizma v 4 vyp. [Almanac on the History of the Baptist Faith in Russia. 4 Issues.]. St Petersburg, Bibliya dlya vsekh. Iss. 1.313 p. Iss. 2. 431 p. Iss. 3.352 p. Iss. 4.302 p.

Kondrashina E. (2014). Zhenshchiny v obshchinnoi zhizni protestantskikh tserkvei v SSSR (1945-1991 gg.) [Women in the Congregational Life of Protestant Churches in the USSR (1945-1991)]. In Gosudarstvo, religiya i tserkov'v Rossii i za rubezhom. Vol. 32. Iss. 1, pp. 151-171.

Kononenko, Yu. (1998). Mozhet li devushka rukovodit' molodezh'yu? [Can a Young Woman Lead Youth?]. In 95 let Tserkvi evangel skikh khristian-baptistov v Novosibirske [95 Years of the ECB Church in Novosibirsk]. Novosibirsk, Posokh, p. 33.

Luehrmann, S. (2011). Secularism Soviet Style: Teaching Atheism and Religion in a Volga Republic. Bloomington, Indiana Univ. Press. 276 p.

Nikol'skaya, T. K. (2002). Russkii protestantizm i gosudarstvennaya vlast'v 1905-1991 godakh [Russian Protestantism and State Power in 1905-1991]. St Petersburg, Izdatel'stvo Evropeiskogo universiteta. $356 \mathrm{p}$.

Orsi, R. (2002). The Madonna of 115th Street: Faith and Community in Italian Harlem, 1880-1950. N. Haven, Yale Univ. Press. 287 p.

Prokhorov, C. (2013). Russian Baptists and Orthodoxy, 1960-1990: A Comparative Study of Theology, Liturgy, and Traditions. Carlisle, Langham Monographs. 487 p.

Prokhorov, K. (Ed.). (2010). Podvig very: unikal'nye svidetel'stva o zhizni khristian v SSSR [Feats of Faith: Unique Testimonials of the Lives of Christians in the USSR]. Omsk, Nauka. 400 p.

Raleigh, D. J. (2012). Soviet Baby Boomers: An Oral History of Russia's Cold War Generation. N. Y., Oxford Univ. Press. 420 p.

Rodstvenniki uznikov Zapadnoi Sibiri [Relatives of Prisoners of Western Siberia.]. (1968). Zayavlenie Predsedatelyu Soveta Ministrov t. Kosyginu (8 avgusta) [Declaration to the Chair of the Council of Ministers, Comrade Kosygin from Relatives of Prisoners from Western Siberia (8 August)]. In Keston Center for Religion, Politics, and Society. SU-Ini6-8-S. 3 p.

Savinskii, S. N. (2001). Istoriya Evangel'skikh khristian-baptistov Ukrainy, Rossii, Belorussii $v 2$ t. [The History of the Evangelical Christians-Baptists of Ukraine, Russia, and Belarus. 2 Vols.]. St Petersburg, Bibliya dlya vsekh. Vol. 2. 1917-1967 gg. 440 p.

Sawatsky, W. (1981). Soviet Evangelicals since World War II. Scottdale, Pennsylvania, Herald Press. 528 p.

Smolkin-Rothrock, V. (2014). 'The Confession of an Atheist Who Became a Scholar of Religion': Nikolai Semenovich Gordienko's Last Interview. In Kritika. Vol. 15. No. 3, pp. 597-620.

Smolkin-Rotrok, V. (2013). Interv'yu s professorom Nikolaem Semenovichem Gordienko [An Interview with Professor Nikolai Semenovich Gordienko]. In Smirnov, M. Yu. (Ed.). Put' uchenogo: Nikolai Semenovich Gordienko [A Scholar's Way: Nikolai Semenovich Gordienko]. Moscow, Osobaya kniga, pp. 25-61.

Williams, S. C. (1996). The Problem of Belief: The Place of Oral History in the Study of Popular Religion. In Oral History. Vol. 24. No. 2, pp. 27-34.

The article was submitted on 02.04.2018 